\title{
Inequality in Household Resources and Amenities in Dhaka City: The Case of Dhanmondi, Pallabi, and Kallayanpur
}

\author{
Shahadat Baser, Shamsun Nahar and M. Maksudur Rahman
}

Department of Geography and Environment, University of Dhaka, Dhaka 1000, Bangladesh

Manuscript received: 15 November 2020; accepted for publication: 26 February 2021

\begin{abstract}
This Paper examines the existing spatial inequalities in residential areas of Dhaka City, the megacity of Bangladesh on the basis of household resources and amenities. The empirical data has been collected through a detailed semi-structured questionnaire from 180 purposively selected respondents in Dhanmondi and Mirpur residential area and Kallayanpur slum area. . The results clearly indicate that there exist significant differences and variations of household resource and amenity indicators, particularly household and housing characteristics, sanitation facilities, water, electricity, and gas supplies, etc. More specifically, the finding reveals that there is a huge gap in tenure systems, income-expenditure, occupational, education and social status, utilities, and physical developments, and these are the prime issues for creating massive inequality in slum area from other residential areas. Furthermore, the slum dwellers are more deprived and neglected from all kinds of urban facilities though they play significant role in informal economy of urban areas as well as in GDP of Bangladesh. Hence, the findings suggest that policymakers should take proper initiatives to address multi-dimensional issues of slum areas to ensure a sustainable environment among residential areas of Dhaka City.
\end{abstract}

Keywords: Spatial inequalities, Household resources, Amenities, Slum, Dhaka City

\section{INTRODUCTION}

Spatial inequality has become one of the prime development characteristics considered across the world (Kanbur and Venables, 2003). In the cities of developing nations, spatial inequalities in income, health, education, and impoverishment present vital economic and political challenges for the governments (Kim, 2008). In addition, cities as the drivers of economic growth where concentrations of individuals and investment, high levels of exchange, economies of scale and proximity, can all contribute to vitality and development. Though all the facilities are agglomerated here, facilities are not equally distributed in city area which is accelerating urban inequalities day by day (Bartlet et al. 2013). Particularly in Bangladesh, Dhaka is immensely densified of population and one of the fastest-growing megacities of the world which accommodates over 20 million population and increasing 0.5 million population every year (Farah et al., 2015; Gruebner et al., 2014; Sinthia, 2013; United Nations, 2018). The

Corresponding author: Shahadat Baser

Email: shahadat.baser@gmail.com

DOI: https://doi.org/10.3329/dujees.v9i1.54861 economic growth of Dhaka city commenced after independence leading to income gap which turned into spatial gaps afterwards (Grant, 2010). These gaps lie in the tremendous migration, poverty, unequal distribution of income and assets, excessive population growth, lack of human resource development and no entry of public services (Farah et al., 2015; Bartlet et al., 2013; Sinthia, 2013; Kanbur and Venables, 2003).

Basically, cities are home of affluent individuals and also a number of the fore most excluded and underprivileged people (Kanbur and Venables, 2003). According to BBS, (2010) Dhaka City has $15 \%$ poor and $4.9 \%$ people are living under the poverty line where urban poverty was $18.9 \%$ (ADB, 2018). Most of the poor people dwell in the slum areas of Dhaka city where resources are very limited (Mondal, 2017; BBS, 2015; Agarwal and Taneja, 2005). In general, urban means developed areas than rural with a high standard of living but there is no possibility to find any single development touch in low-income residential areas. Their living expenses are higher in per square feet rent than high-income residential areas. Even then, they don't get enough standard public facilities where most of these facilities/amenities are shared and highly inadequate especially water, sanitation and kitchen facilities (Grant, 2010; Begum and Sen, 2005). 
Notwithstanding household resources and amenities are the physical assets required to have access by urban dwellers which refer to the desirable conditions of a community and also necessary for social reproduction (Aminu, 2017). Prime indicator of a household resource is tenure security which indicates the standard living of life. Along with that affordable housing is the basic requirement which create social value and ameliorate economic growth( Hossain, 2004, 2005). Basically, the household resources are defined by some indicators: land ownership, types of occupancy, housing nature, water supply, sanitation facilities, drainage facilities, access road, electricity supply, school enrollment, civic facilities income, savings and credits activities and social problem (Bandara et al., 2017; INSEE, 2016; Heath, 2014; Sekhampu andand Niyimbanira, 2013; Townsend, 1979). Limitations in household resources of middle-income and low-income than high-income residential areas are income inequalities, occupational status, social status, advance use of technology, spatial locations. In Dhaka city, those problems are accelerating day by day due to excessive poor population and unequal distribution of resources and amenities (Sekhampu andand Niyimbanira, 2013; Grant, 2010; Jahan andand Oda, 2000). Moreover, people are continuously competing with each other to live in an area with good amenities which are highly insufficient throughout the city since those are presented in well transport network, access to the shopping, entertainment, open space, green belt, healthcare and educational institutes. These amenities assist people to elicit from physical, cognitive, social or emotional limitations and can increase life expectancy and standard of living (Warwick, 2018; Parry et al., 2012; Aderamo and Aina, 2011; Bhagat, 2010; Mc Granahan, 1999). But lack of amenities are the causes of mental stress and disorder, mood change, personality disorder, suicide, health problems. Abundance of neighbourhood amenities apparently increase living conditions and also develop a community a much-planned way. People who have no access in these resources and amenities are not part of the elegant society so they always have to confront deprivation and negligence from access to proper public facilities and infrastructural development (Murali andand Oyebode, 2004).
So, the main thrust of this research is to find out the existing inequalities in household resources and amenities among high-income, middle-income and low-income residential areas in Dhaka city. It is very normal that low-income residential areas will have less facilities compared to high residential areas which is known to all. But in reality, high income residential areas are more benefited by facilities, resources and advantages than low-income residential areas. This study will focus all those spatial inequalities in household resources and amenities of selected areas along with Dhaka city as a comparative manner. The specific objectives of this study are a) to assess the existing inequalities in landuse pattern among residential area in Dhaka city; b) to identify the inequalities in household resources of the study areas; c) to evaluate the availability and scarcity of amenities in the study areas.

\section{METHODOLOGY}

\section{Study Area}

Dhaka Metropolitan area was chosen as the study area due to agglomeration of vast population in residential areas. There are various types of residential areas such as high-income, upper middle-income, middle-income, lower middle-income, and also some sorts of mixed-up residential areas. That's why for better understanding of inequalities through different perspectives, three different residential areas were selected purposively which are situated nearly each other. One is Dhanmondi $(10,11$, and 12) residential area (R/A) which has been selected for the agglomeration of high-income groups and also recognized as a first planned residential area in Dhaka city which is developed by the Public Works department in the 1960s. 


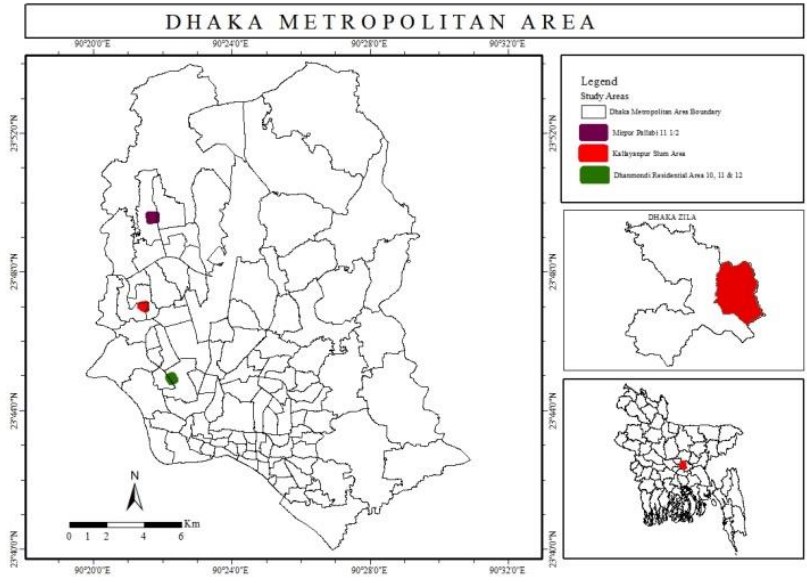

Source: Field Study, 2018

Figure 1: Study Locations in Dhaka Metropolitan Area

The area is the nearly central part of the city and total $2.179 \mathrm{~km}^{2}$ is designed with a grid pattern plan with the road (Haque and Asami, 2011). Another is Mirpur Pallabi, selected as middle-income residential area which is near to the Rupnagar and Eastern Pallabi which is under Dhaka North City Corporation and quite planned area. The surveyed area occupies about $2 \mathrm{~km}^{2}$ area with 288 households. The other is Kallayanpur slum area known as Kallayanpur Pora Bastee has been selected as low-income group and situated at Kallayanpur ward of Mirpur Thana in Dhaka City (Figure 1). The total household and population of Kallayanpur slum is 2,184 and 8,129 (male 4,126, female 3,998 and others 5), respectively (BBS, 2015).

\section{Tools and Techniques}

Basically, the study was carried out on the basis of quantitative method. Survey tool was used to identify the socio-economic characteristics of the study areas. A detailed semi-structured questionnaire survey was conducted to collect empirical data. The questionnaire in Bangla was developed highlighting socio-economic issues to explore the inequalities. In addition, the discussions with various researchers were added and negotiated with experts on this field. The pre-testing and pilot survey were carried out with local residents prior to the main study.

. Face-to-face questionnaire survey was conducted for data collection. For the selection of the participants, systematic sampling technique was used purposively due to some difficulties occurred during data collection. Most residents of high- and middleincome residential areas were unwilling to contact with researchers owing to their tight schedule of businesses, jobs and also for feeling insecurity with unknown persons. In some apartment buildings, it was strongly prohibited for outsiders to enter into the gate. As a consequence, the normal sampling interval varies in study areas. For example, each 4th household were selected in certain residential areas, while every 10th household was selected in other area. But such kind of problems didn't take place in slum area. But in both the cases, respondents showed unwillingness about disclosing their incomes and savings. However, each participant was told about the purpose and the potential use of the dataset prior to the interview. They were also told that, at any given time, they were entitled to withdraw from the survey without repercussions. Households' head over 20 years old were targeted and anonymity was ensured for all participants. In the absence of the household head, an adult member of the household was interviewed. The study has been surveyed total 180 households where 60 households from each study areas. In addition, the secondary data were collected from government and non-government official documents and statistics, yearly reports, various books, research papers, journals, maps, daily newspapers etc. Also, an indepth study has been conducted to collect data and information from the study areas. The collected data were analyzed by computer based specific statistical software like SPSS and Microsoft excel 2016. Map of the study areas was prepared by using Arc GIS 10.4. The analyzed data were presented using descriptive statistics as a qualitative manner on the basis of the respondents' shared opinions and perceptions to explore the real scenario of existing inequalities in Dhaka City.

\section{RESULTS AND DISCUSSIONS}

\section{Household Characteristics}

\section{Family Structure}

Likewise, family structure is an important factor among household resources. Nuclear families are the mostly dominant in city landscapes. Table 1 shows that most of the families are nuclear even though a little less in Kallayanpur slum area (56 percent) but indicates an ideal urbanization. Basically, the study indicates that about 73 percent family are nuclear in

Table 1: Comparative Scenario of Family Structures in Percentage $(\mathrm{N}=180)$ 


\begin{tabular}{lllll}
\hline $\begin{array}{l}\text { Residential } \\
\text { Areas }\end{array}$ & Nuclear & Joint & Extended & Single \\
\hline Dhanmondi & 73 & 14 & 2 & 1 \\
Pallabi & 100 & - & - & - \\
Kallayanpur & 56 & 28 & 12 & 4 \\
\hline & & & Source: Field Study, 2018
\end{tabular}

Dhanmondi where 100 percent in Pallabi area as for newly planned and developed area. Furthermore, cheap rent is another reason for the high agglomeration of nuclear families in Mirpur Pallabi area. A substantial diversity is revealed in in Kallayanpur slum area where 28 percent are joint, and 12 percent are extended because of social bonding and scarcity of space mainly. Even Dhanmondi residential area has $14 \%$ joint family and only 2 percent are extended where most of them are apartment or building owners. Therefore, it can be asserted that affluency creates segregation in family structures.

\section{Educational Qualification}

Education is very basic demand in human life. As an aristocrat area, Dhanmondi is enormously enriched with educational facilities where existed 44 schools, 6 colleges, 12 Universities and 12 other educational institutions (Coaching, Computer Learning Center, etc.) (Afrin et al., 2012). These scenarios represent sufficient education facilities existed in Dhanmondi R/A except other study areas. As a result, in Dhanmondi R/A, the respondents are highly educated where about $66 \%$ people are graduated and 24 percent are post graduated. At the same time in Pallabi area, about $34 \%$ people are graduated and 14 percent are post graduated and also a significant number of dwellers have formal education like SSC and HSC (Figure 2).

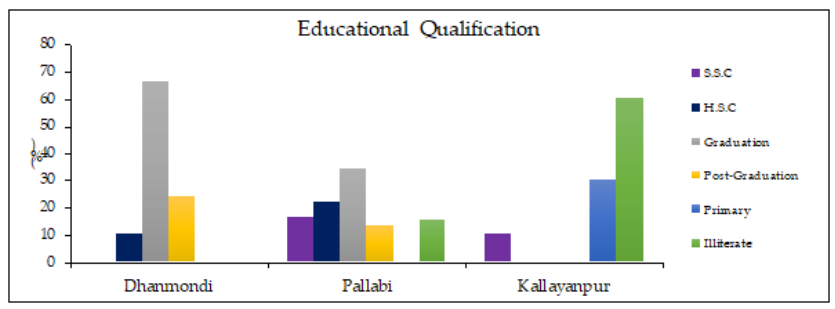

Figure 2: Comparison of Educational Qualifications

Source: Field Study, 2018

On the other hand, mostly illiterate people $(60 \%)$ dwell in Kallayanpur slum area (Fig. 2). Basically, this scenario is quite normal as low-income people abundant in Kallayanpur slum. The fact is that the more academic qualified person makes the highert monthly income whereas less educated persons earn less. Higher levels of education ensure better economic and social status ( Hossain et al., 2018). Only $30 \%$ were educated up to primary level (Figure 1) where only two primary education centres are existed, run by NGO.

The scenarios are significantly similar with other cities, according to ( Hossain et al., 2010), the education level in the slum area of Khulna city and Rajshahi city are very poor in the context of primary to higher secondary levels. Overall illiteracy rate of Khulna city is about $60 \%$ whereas in Rajshahi about $90 \%$. Nevertheless, Only $1.4 \%$ of respondents had a graduate-level education in Rajshahi whereas in Khulna the figure was nothing (Badhan et al., 2017; Hossain et al., 2010; Latif et al., 2016).

\section{Income and Expenditure Patterns}

The study reveals an uneven and unequal distribution of income where Dhanmondi is the home for $100 \%$ high salary individuals of whom a large portion are connected with business exercises or corporate sectors. More specifically, about $40 \%$ of individuals' month to month salary is above Tk. 175,000 and the very least Tk. 75,000 which is only (8\%). But Mirpur Pallabi area is inhabited by lowermiddle, middle-class families and high-income group (Ahmed et al., 2014) where about $17 \%$ people have above fifty thousand taka and these numbers are increasing day by day for the agglomeration of industry and high officials in newly built apartments. In addition, with $64 \%$ peoples' income is in between Tk. 30,000-40,000.

Table 2: Comparative Patterns of Monthly Expenditure and Deposit (\%)

\begin{tabular}{llll}
\hline & Dhanmondi & $\begin{array}{l}\text { Mirpur } \\
\text { Pallabi }\end{array}$ & Kallayanpur \\
\hline Expenditures & & & \\
Rent & 15 & 39 & 20 \\
Education & 50 & 41 & 4 \\
Food & 28 & 18 & 48 \\
Health & 5 & 2 & 4 \\
Others & 2 & - & 24 \\
Deposits & & & \\
Bank & 58 & 91 & 2 \\
Financial & 34 & - & - \\
Institutions & & & \\
\hline
\end{tabular}




\begin{tabular}{llll}
\hline Give to Loan others & - & 6 & 40 \\
$\quad$ Within House & 8 & 3 & - \\
No & - & - & 58 \\
Total $(\mathrm{N}=180)$ & 100.0 & 100.0 & 100.0 \\
\hline
\end{tabular}

Source: Field Study, 2018

On the Contrary, in Kallayanpur slum area, the inhabitants are related to informal economic activities where 76 percent household's income ${ }^{1}$ below 10,000 taka which represents their living standards. Most of the people are employed in driver of various forms of vehicles like CNG, taxi, office car, rickshaw driving, wheelbarrow or van pushers, garments sector, masons, day labourers, carpenters, office drudge, low-grade worker in private, government or semi-government organization (Latif et al., 2016; Alam andand Rabbani, 2007; Islam et al., 2006). At the same time, the females are engaged in garments sector, embroidery, sewing, making ready food, maid both in homes and offices etc. (Sinthia, 2013).

Basically, people are bound to spend their incomes on daily needs (Asim et al., 2012). The study reveals that expenditure is substantially high in Dhanmondi area than other study areas which is more than Tk. 50,000 simply indicating high standard of lifestyles. But Pallabi area indicates variety of expenditure levels (<Tk. 30,000>) that means variety of lifestyles because of variety of income groups. Table 2 indicates that the dwellers of Dhanmondi R/A spend $50 \%$ of total expenditure only for their children education and for food $28 \%$ where Pallabi spends $41 \%$ and $18 \%$ respectively. But Pallabi dwellers have to pay a large portion (39\%) for house rent where Dhanmondi expends only $15 \%$ compare to their expenditure levels per month. Moreover, a maximum portion of the average family expenditures is to afford the rent of living spaces(Mahbub-Un-Nabi and Hashem, 2007; Niger, 2012). Therefore, it is clearly asserted that most of the inhabitants of Dhanmondi are extravagant for their higher standard of Living and Mirpur Pallabi is also on same direction.

But in the Kallayanpur Slum area, the study found that people about $76 \%$ expend below Tk. 10,000 per month. A large portion (48 percent) of the monthly income is spending to buy food and 20 percent on rent as well (Table 2) which is quite similar with Korail slum (Latif et al., 2016; Sinthia, 2013). Very few slum

\footnotetext{
1“"Income refers to wages, salaries, profits, rents, and any flow of earnings received" (Hossain et al., 2018).
}

dwellers have a little savings below 10,000 Tk. where most of them responded that they can't save anything at the end of the month. Contrarily, the amount of savings per month is substantially high in Dhanmondi where 100 percent respondents have savings and Mirpur Pallabi has only $13 \%$.

For the deposit, maximum people deposit their money/currency in bank and financial institution such as different Bima Corporation. In Dhanmondi R/A, about 58\% households use bank services and about $34 \%$ households use other financial institutions (Table 2). Some are deposited in both banks and financial institutions. This area is incorporated with 15 banks which indicate their close connectivity with banks (Afrin et al., 2012). In Mirpur Pallabi, about 91 percent use bank services where only $2 \%$ in Kallayanpur slum area and about $40 \%$ people give loan to others as a small amount for temporary solution (Table 2). Indeed, significant households were not willing to talk about their savings and deposit. The findings clearly revealed the uneven lifestyles and livelihood patterns of households among the study areas.

\section{Housing Characteristics}

\section{Landuse Patterns and Ownership Types}

In Dhaka city, man and land ratio is proportionately fewer and still highly uneven (Stubbs andand Clarke, 1996).The finding reveals that in Dhanmondi, maximum land is used for residential purpose about $72 \%$ where only $10 \%$ for commercial and $18 \%$ as mixed use (Table 3). Because educational institutions ${ }^{2}$, commercial establishments ${ }^{3}$ and health care centres ${ }^{4}$, etc. as non-residential uses have increased in number due to the necessity of dwellers. In addition, Dhanmondi, a planned residential area, is the prime choice of the real estate developers for apartment business for its social and physical environment with better accessibility ( Ahmed et al., 2009; Mahbub-UnNabi and Hashem, 2007). The study found that only $10 \%$ houses has been built by the owners but about 42 percent landowners have developed their houses through Real State Companies by sharing ownership of

\footnotetext{
${ }^{2}$ Educational Institutions are Schools, Colleges, University and Other Institutions (Coaching, Computer Learning Center, etc.) (Afrin et al., 2012).

${ }^{3}$ Commercial establishments are Banks, Community Center, Departmental Store \& Confectionary, Fast Food \& Restaurants, NGO Offices, Miscellaneous Offices, Other (Business Enterprise not including in listed categories), Shops, Tailor \& Boutique \& Beauty Parlor (Afrin et al., 2012).

${ }^{4}$ Health care centers are Clinic, Hospital, Pathological Lab, Diagnostic Center (Afrin et al., 2012)
} 
the buildings. That's why $36 \%$ household are only apartment owner due to sale by Real estate companies. On the other hand, In Mirpur Pallabi area 80\% land used both for residential and commercial (Table 3 ). The mixed uses have increased due to the shortage of land, excessive demand for commercial spaces (government, NGO and private), and also for shopping mall facilities and the growth of garments industries (Ahmed and Mohuya, 2013). Table 3 also shows that about 50 percent dwellers are renter and $20 \%$ are apartment owner who are mostly worked by walking distance. Only 20\% respondents of Pallabi are the owner of the land and building which means the area is agglomerated by out-migrants.

Table 3: Comparative Scenario of Landuse Patterns and Ownership Types (\%)

\begin{tabular}{|c|c|c|c|}
\hline & Dhanmondi & $\begin{array}{l}\text { Mirpur } \\
\text { Pallabi }\end{array}$ & $\begin{array}{l}\text { Kallaya } \\
\text { npur }\end{array}$ \\
\hline \multicolumn{4}{|l|}{ Landuse Type } \\
\hline Residential Building & 72 & 20 & 58 \\
\hline Commercial Building & 10 & - & 6 \\
\hline $\begin{array}{l}\text { Mixed (Residential and } \\
\text { Commercial) }\end{array}$ & 18 & 80 & 36 \\
\hline \multicolumn{4}{|l|}{ Ownership Type } \\
\hline Owner (Land + House) & 10 & 20 & 36 \\
\hline $\begin{array}{l}\text { Owner of land but given to } \\
\text { the real estate company }\end{array}$ & 42 & - & - \\
\hline Renter & 12 & 50 & 64 \\
\hline Apartment Owner & 36 & 20 & - \\
\hline Total $(\mathrm{N}=180)$ & 100.0 & 100.0 & 100.0 \\
\hline
\end{tabular}

Table 3 shows that in Kallayanpur slum, about 58 percent land is utilized for residential purpose and 34\% for the mixed uses without any planning. Because slums are the constantly undeliberate development of Dhaka city (Sinthia, 2013). According to Farah et al. (2015), over 37\% of total population of Dhaka city dwell in slums which is only $4 \%$ land of Dhaka city where maximum slum dwellers live with rent. The study reveals that 62 percent of slum dwellers live in Kallayanpur with rent and 36 percent residents are the owner ${ }^{5}$ of both land and house (Table 3 ).

\section{House Size and Rent}

In Dhaka city only 5\% dwellers are high income group where middle income and lower income group

\footnotetext{
${ }^{5}$ Here owner means who has occupied the government land in illegal way and claimed themselves as land owners.
}

are $45 \%$ and $50 \%$ respectively of total population (Barua et al., 2010). Dhanmondi R/A is one of the aristocrat residential areas in Dhaka city due to living environment, better communication with work places ${ }^{6}$ and close to educational facilities (Hasnat andand Hoque, 2014; Afrin et al., 2012). From the study it was found that 42 percent apartment or flat size of Dhanmondi (10, 11 andand $12 \mathrm{~A})$ is about 3,000 to 3,500 sq. ft. and $22 \%$ are 3,500 to 4,000 sq. ft. and only $4 \%$ is below 2,500 sq. $\mathrm{ft}$. which clearly indicates the aristocracy level of dwellers and also their organized living environment (Figure $3 b$ ).

Contrarily, the slum dwellers of Dhaka city live in very tiny space mostly in a single room (Islam et al., 2006; Sinthia, 2013). The study shows that about $36 \%$ of the household size is under $1,00 \mathrm{sq}$. ft. and 36 percent dwellers stay in between 2,00-4,00 sq. ft. and only $8 \%$ dwells above 4,00 square feet (Figure 3a). Also they have to impart kitchen, shower and toilet facilities, are very unhygienic (Sinthia, 2013). According to Islam et al. (2006), about 20 percent slum dwellers live in below 76 sq. ft., $61 \%$ in between $76-1,00$ sq. ft. and only $2 \%$ above 1,25 sq. ft. where in Chattogram is $34 \%$, Barishal $43.9 \%$, Rajshahi $33 \%$ and Sylhet $15 \%$ dwellers live in below 100 sq. ft.

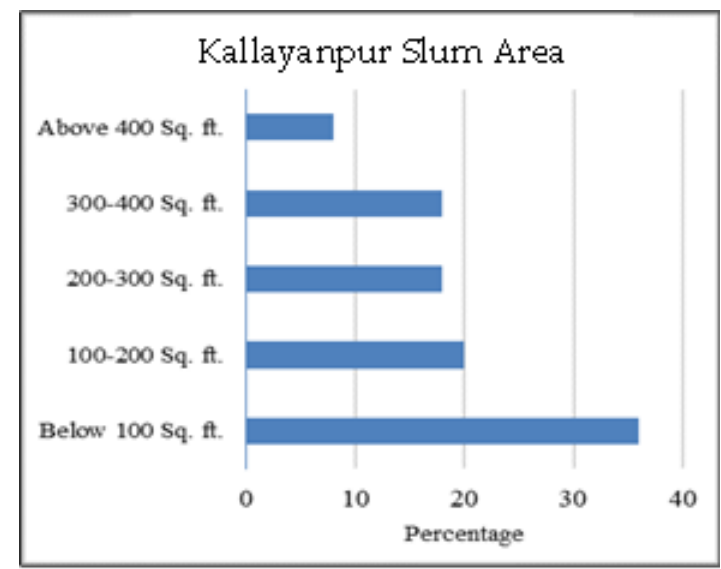

3(a)

\footnotetext{
${ }^{6}$ Working centers like Motijheel, Farm gate, new market, etc. (Labib et al. 2013)
} 


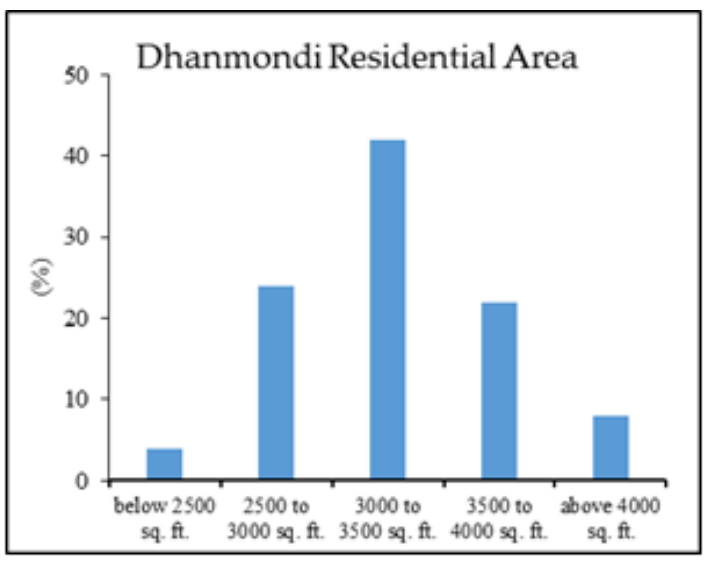

3(b)

Figure 3: Comparison of House/ Apartment size

Source: Field Study, 2018

On the other hand, in Mirpur area, around 29 percent residents demand 1,201-1,600 sq. ft. but 1,0011,200 sq. $\mathrm{ft}$. has the maximum demand where only 9 percent demand less than $800 \mathrm{sq}$. ft. The house renters are bound to pay Tk. 13,690 per Sq. ft. in Dhanmondi and Tk. 5,700 per sq. ft. in Mirpur set by estate developers (Labib et al., 2013). For the quite high rent in Dhanmondi, middle class families force to accommodate in less space like measly residential units or cheap house rent areas (Niger, 2012). But in slum areas, most of the respondents build their houses by their own costs. Most people lived here with rent must pay around Tk. 1,000 but not more than 2,000 Tk. Maximum households belong 5-10 members and more in each single room with various sizes which indicate a highly densified area. Surprisingly, slum people paid more per square feet which is more than the residential people of Gulshan. Dhanmondi etc. Nevertheless, slum dwellers have no basic access to their basic rights (The Daily Star, 2019).

\section{Access to Electricity Facilities}

For the economic prosperity and poverty alleviation, electricity facility is a crucial prerequisite (Sagebiel andand Rommel, 2014; Hewett andand Montgomery, 2001).Without electricity, community people have narrow access to healthcare, public lighting and amusement services (Pachauri et al., 2013). Dhaka as a megacity with over population where electricity is probably the best of all provided facilities by Dhaka Electric Supply Authority (DESA) and Dhaka Electric Supply Company (DESCO) (Hossain, 2006). More than $85 \%$ electricity, used in residential, commercial and industrial sectors, is based on natural gas (Alam andand Rabbani, 2007). But for the poor management systems, all the areas are not supplied parallel for inadequate supply and some get frequent breakdowns (Hossain, 2006).

The study shows that in Dhanmondi R/A, over $32 \%$ people have claimed low-level of load shedding whereas $77 \%$ people of Mirpur Pallabi claim high level of load shedding (Figure 4a), though these areas have $100 \%$ electricity connection (Ahmed et al., 2014). They also claimed it hampers on students' education badly and households andand official tasks. The condition is basically taken place in summer season because of high consumption of electricity for using all kinds of luxurious appliances. For the illegal connections, up to $30 \%$ is systematic loss and high amounts are paid by residents to local suppliers (Hackenbroch et al., 2008; Hossain, 2006). The study also demonstrates that about $68 \%$ people of Dhanmondi and $72 \%$ of Mirpur claimed that they have to pay high price to get break-free electricity though it's not a very big deal for the dwellers of Dhanmondi (Figure 4b).

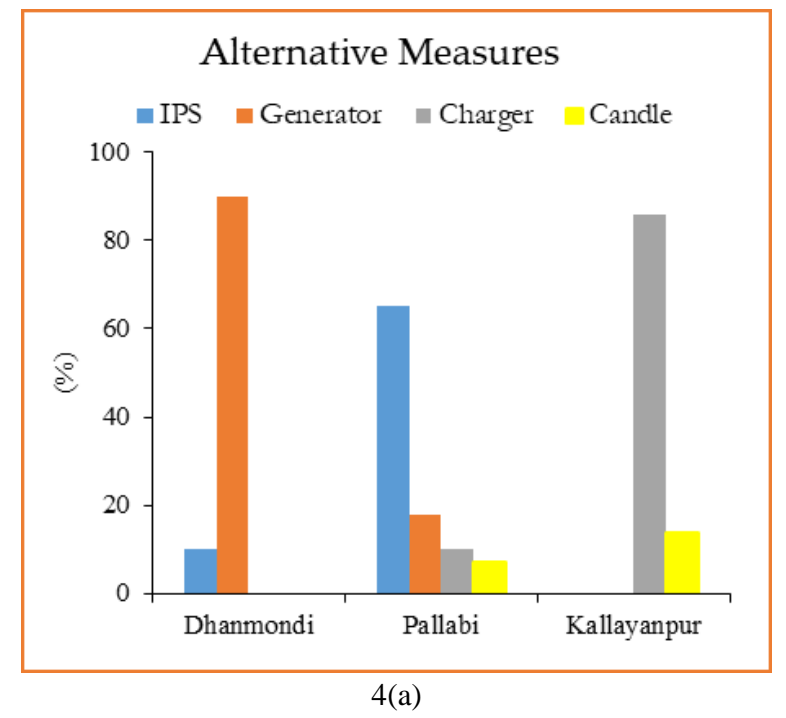




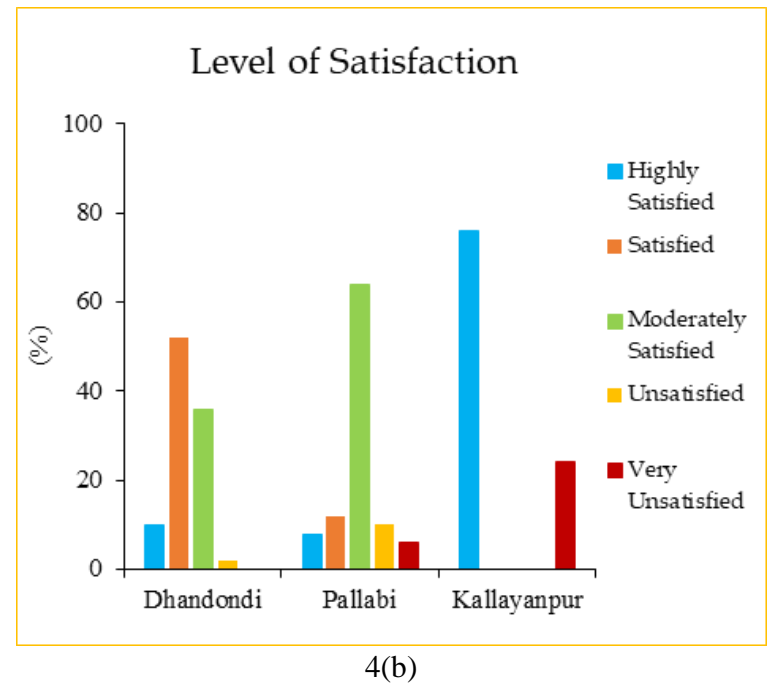

Figure 4: Comparative Study of Quality of Load Shedding and Electricity problems.

Source: Field Study, 2018

On the other hand, the scenarios are significantly miserable in slum areas of Dhaka city. In 2005, 95.4\% households of Dhaka slum areas are connected with electricity which becomes $73 \%$ in 2009 because of eviction and very poor andand inadequate supply in spite of being densely populated (Braun andand Aßheuer, 2011; Kamruzzaman andand Hakim, 2016; Hossain, 2008; Kimani-Murage andand Ngindu, 2007; Islam et al., 2006; Kumar andand Aggarwal, 2003). The study found that in Kallayanpur slum area, 58 percent residents face medium level of load shedding where $20 \%$ face high level of load shedding though they hardly use luxurious products ${ }^{7}$.Furthermore, about $48 \%$ people claimed for facing problems in every work for electricity breakdowns where $20 \%$ dwellers have 'no problem' in electricity (Fig. 4b). Here 'no problem' means they have no luxurious commodities. If they can just run a light and fan it's a big facilities/ pleasure for them.

Basically residential energy consumption changes with income patterns, electricity price, typeand size of the residential dwelling, ownership of appliances and household sizes (Yalcintas and Kaya, 2017). Residents in urban areas have enhanced their energy consumption over the period and learnt to cope up with electricity crisis through alternative measures

\footnotetext{
${ }^{7}$ Luxurious products are refrigerator, micro-wave oven, air conditioner,
} television, washing machine etc. though middle and higher income households are willing to pay more for reliable and assured connection (Hanisch et al., 2010). In Dhaka city, for load shedding people are force to buy alternative measures like IPS, generator, charger light etc.

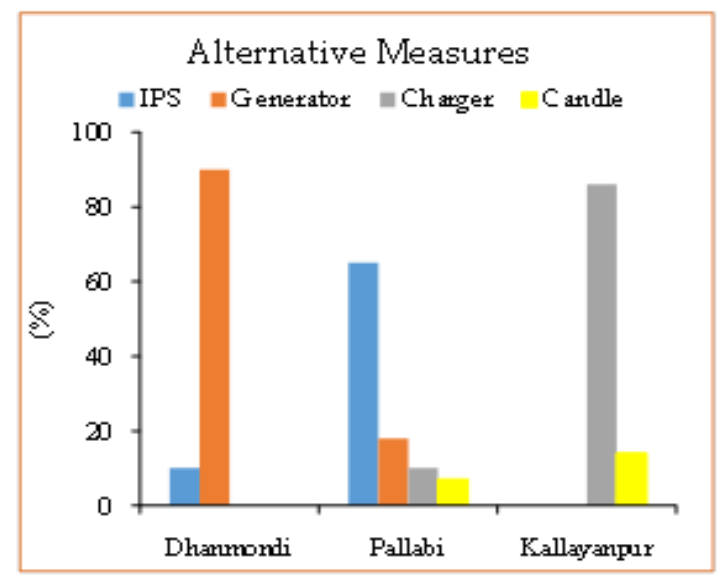

$5(a)$

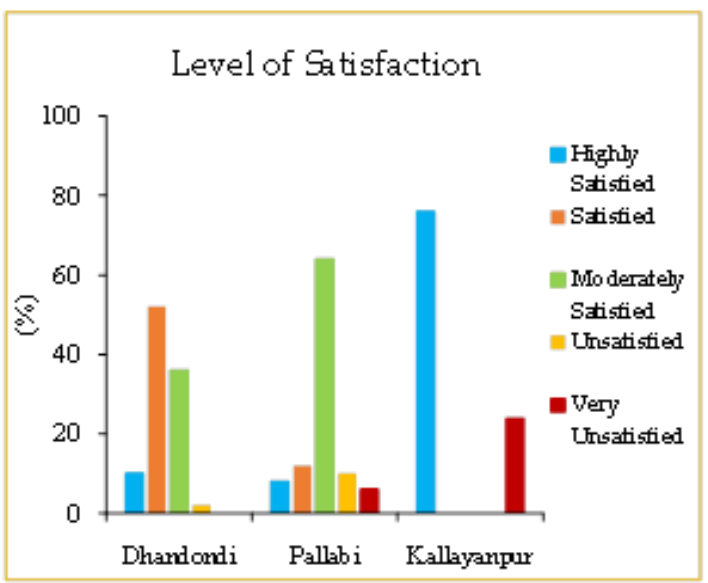

Figure 5: Resident Perceptions on Alternatives Measures and Satisfaction

Source: Field Study, 2018

The research study gets that about $65 \%$ residents in Mirpur area used IPS where Kallayanpur people never think about IPS as an alternative measure. Again, generator is mostly used in Dhanmondi area (90 percent) because of their affordability. Practically majority dwellers of Dhanmondi and Mirpur Pallabi areas are pretty much happy with the nature of power administration because of full time backup through generator service this problem do not bother them at 
all. Due to high use of modern electric goods like air conditioner, washing machine etc. the power consumption rate is very high in Dhanmondi. On the contrary, about 86 percent use charger light in Kallayanpur slum area and candle is used by $15 \%$ which also represents their abilities as well. Almost every one of other two study areas said that they are satisfied more or less with the quality of electricity service. But $76 \%$ people in Kallayanpur slum claim that they are highly satisfied with their electricity quality (Fig. 5a and b). Because they replied, "If we can just run light and fan it may be great achievement/ pleasure for us" which is actually unimaginable in Dhanmondi and Mirpur residential area.

\section{Access to Water Facilities}

Particularly Dhaka City have acute problem in water and sanitation (Hossain, 2006) particularly in low income groups whom over $80 \%$ have no legal access of water (Farah et al., 2015 cited in Dana, 2011). At present, $60 \%$ of city's population have access to municipal piped water by DWASA (quality is poor and need to boil for drinking) and $15 \%$ form private wells and surface water (Hossain, 2006). But the finding reveals that Dhanmondi R/A has 100\% access to clean and safe water where $97 \%$ access in Mirpur Pallabi area (Table 4). But $90 \%$ people have to boil water for safe drinking in Mirpur area (Ahmed et al., 2014). On the other hand, slum dwellers of Dhaka city are unprivileged to urban facilities such as inadequate safe water, toilet facilities and garbage disposal ( Hossain, 2008). However, for availability of tap or tube-wells in slum areas, $66 \%$ people use tubewell water for drinking and $24 \%$ use City Corporation's supplied water for cooking and other purposes (Farah et al., 2015; Angeles et al., 2009).

Table 4: Water Quality as perceived by Respondents with Alternatives Measures for Problems

\begin{tabular}{|c|c|c|c|}
\hline & Dhanmondi & $\begin{array}{l}\text { Mirpur } \\
\text { Pallabi }\end{array}$ & $\begin{array}{l}\text { Kallayanp } \\
\text { ur }\end{array}$ \\
\hline \multicolumn{4}{|l|}{ Water Quality } \\
\hline Clean & 100 & 97 & 34 \\
\hline Dirty & - & - & 18 \\
\hline Odor & - & 3 & 48 \\
\hline \multicolumn{4}{|l|}{ Problems } \\
\hline Water-borne & - & - & 46 \\
\hline \multicolumn{4}{|c|}{ Disease } \\
\hline \multicolumn{2}{|c|}{ Expense increases for buying water - } & - & 24 \\
\hline No Problem & 100 & 100 & 30 \\
\hline \multicolumn{4}{|l|}{ Alternative Measures } \\
\hline Community Water Service & - & - & 42 \\
\hline
\end{tabular}

\begin{tabular}{llll}
\hline Collect from WASA & - & - & 40 \\
Water Pump & - & - & 18 \\
No Alternatives & 100 & 100 & - \\
$\begin{array}{l}\text { Level of Satisfaction } \\
\text { Highly Satisfied }\end{array}$ & 34 & 26 & - \\
Satisfied & 60 & 74 & - \\
Moderately Satisfied & 6 & - & - \\
Unsatisfied & - & - & 86 \\
Very Unsatisfied & - & - & 14 \\
Total (N=180) & 100.0 & 100.0 & 100.0 \\
\hline & & Source: Field Study, 2018
\end{tabular}

From the study it reveals in Kallayanpur slum area that currently $42 \%$ people collects water from community service and $40 \%$ from WASA. Furthermore, about $48 \%$ respondents claimed that the supply water contains odor of bleaching powder and 18 percent claimed dirty. At the same time, for the illegal connections of DWASA supplied water (poor quality), about 24 percent residents pay high amounts per month to the local (Mastaans) suppliers where high residential areas have no issues like that (Ahmed, 2014; Hackenbroch et al., 2008; Cohen, 2006). Without that, Kallayanpur slum dwellers also face various waterborne diseases for using such water which is argued by 46 percent individuals. These occur mostly in rainy season for mixing up the local waste with broken water supplied pipe lines. In where Dhanmondi and Pallabi residents react that they have no issues in water.

In addition, for hardly scarcity in water, the dwellers of Dhanmondi and Pallabi area don't use any alternative measures. But Kallayanpur slum dwellers face extreme water scarcity which force them to utilize alternative sources. The study found that currently $42 \%$ people collects water from community service and $40 \%$ from WASA, though the water quality is poor and contains odor (major problem) andand dirt (Table 4). Few people use lake water for daily activity and some bought outside with monthly payment (Sinthia, 2013; Hackenbroch et al., 2008). According to Hanchett et al., (2003), the slum dwellers pay tk. 2 in every day for their water, though they don't generally have the cash to save also. Without this, the dwellers can't get enough water without paying and often they have to fight each other to collect water. Moreover, slum dwellers cannot directly drink the supplied water. They have to boil or filter or both for safe drinking water for which $86 \%$ people claimed unsatisfied and 14 percent are very unsatisfied. Conversely, $60 \%$ and $74 \%$ dwellers of Dhanmondi and Mirpur Pallabi are satisfied though about $34 \%$ and $26 \%$ residents expressed their highly 
satisfaction on water facilities (Table 4). At the same time, in Dhanmondi R/A, few respondents complained that sometimes the supplied water by WASA contains odor for which they have to buy safe drinking water.

\section{Access to Gas Supply}

The study explores that gas supply facility is substantially rich in Dhanmondi R/A for agglomeration of high-income groups. That's why people don't have to face any scarcity of gas. But in Mirpur area, the people have lots of problems though they have piped gas connection from Joydebpur, Gazipur (CGSs) by Titas (www.rajukdhaka.gov.bd). The Study reveals that 82 percent dwellers uttered that gas facility is available only morning, evening, and night for two or three hours which is very acute in winter season. There is also existence of illegal gas connection which is another cause and creates tremendous problem in cooking, responded be $25 \%$ and $43 \%$ dwellers of Mirpur area respectively (Table 5).

Table 5: Comparative Scenario of Gas Quality and Gas Crisis Problems (\%)

\begin{tabular}{llll}
\hline & Dhanmondi & $\begin{array}{l}\text { Mirpur } \\
\text { Pallabi }\end{array}$ & Kallayanpur \\
\hline $\begin{array}{l}\text { Quality of Gas } \\
\text { Remains Same All Day }\end{array}$ & 100 & 3 & - \\
$\begin{array}{l}\text { Remains only morning/ } \\
\text { evening/night }\end{array}$ & - & 82 & - \\
$\begin{array}{l}\text { Intensity Decrease in Winter } \\
\text { No Supply of Gas }\end{array}$ & - & 15 & - \\
$\begin{array}{l}\text { Problems for Gas Crisis } \\
\text { Problem in cooking }\end{array}$ & - & - & 100 \\
Illegal use gas & - & 43 & - \\
$\begin{array}{l}\text { Increase the Expanse } \\
\text { No Problem }\end{array}$ & - & 25 & - \\
Total (N=180) & 100 & 32 & - \\
\hline
\end{tabular}

Source: Field Study, 2018

On the contrary, there is no gas supply connection in Kallayanpur slum area but very few households use cylinder gas for their little bit affluence. Previous study showed that about $58 \%$ slums of Dhaka city have access to gas for cooking (Mohit, 2012) which was $30.36 \%$ in 1996 and became $57.6 \%$ of households in slums in 2005 (Angeles et al., 2009; Islam et al., 2006). Other slums of Bangladesh like Barishal, Khulna and Rajshahi have no facility of gas supply but Sylhet and Chattogram have only $16.1 \%$ and
$27.9 \%$ of slum households respectively (Islam et al., 2006).

The study also explores that for alternative measures, about $92 \%$ of residents of Dhanmondi use electric oven where in Pallabi area, about $85 \%$ residents use cylinder gas and $7 \%$ people use electric oven and $4 \%$ people use Chimney and stove. On the contrary, about $70 \%$ of Kallayanpur slum dwellers use wood and $26 \%$ use cylinder gas for cooking which is bought by their own cost. Some slum dwellers also use biomass as wood, straw, cow-dung and wastepaper and kerosene fuel (Latif et al., 2016; Mensah andand Adu, 2015; Alam andand Rabbani, 2007; Hossain, 2006). However, more than $90 \%$ dwellers of Dhanmondi expresses that they are highly satisfied with their gas facilities and quality where only 23 percent are satisfied more or less in Mirpur Pallabi area. Actually, most of them (more than 70 percent) are unsatisfied for existing miserable gas services. But in Kallayanpur slum, more than $90 \%$ dwellers are very unsatisfied because they haven't got yet any supplied gas. Therefore, the utility facilities clearly represent a rapid inequality among residential areas in capital city of Bangladesh.

\section{CONCLUSION AND RECOMMENDATIONS}

This paper attempts to elucidate the numerous complex socio-economic conditions and challenges of urban dwellers. The analysis explores root issues of the slum problems and has indicated how these problems are hampering towards a sustainable city. The result clearly indicates that the livelihood condition of lower, lower-middle income groups, specifically slum settings in Dhaka city is substandard and densely populated with scarce and limited household resources, public goods provision, and poor quality of civic amenities. The findings substantiate that household resources and amenities are not uniform in these areas but represent overall scenarios of the major cities of Bangladesh though inequalities in living conditions are very common in a megacity. But generally, the evidence indicates that inequalities are more extreme within cities than elsewhere. These three areas people are collectively important because they play vital role in accelerating the economy as well as GDP of Bangladesh. But in every sector, the slum people are deprived from their actual rights like low level of income, inadequate sanitation services, 
utility facilities, substandard housing and the crammed environment which might have impacted on the environment that led to higher morbidity among the dwellers.Moreover, the people of slum areas play a vital role in informal economic activities of Dhaka city where around $75.2 \%$ of urban population engaged in informal economy in 2013 (BBS, 2015, 2016; Mondal, 2017; Zayeed, 2016).On the contrary, Dhanmondi is well recognized as one of the highest income residential areas of Dhaka city. Mirpur Pallabi area is also growing under planning activities. Here, the urban environment and residential neighborhoods are planned with proportion of population. Per capita road is sufficient, the service facilities are well available. The overall environmental pollution level is tolerable and more suitable residential zone in Dhaka city. Therefore, it needs to be lessened those inequalities to make our city 'Resilient'.

Yet the slums are absorbing a larger segment of the urban population, especially migrants. A holistic solution is also needed to meet housing needs in slum areas with municipal facilities. In addition, the eventual displacement of slums and squatter settlements with better residential quarters is still a policy issue for government and local agencies. In this respect, government and private developers should apply down payments and loan facilities and construct appropriate low-and middle-income housing for the affordable dwellers in suitable places.

Now, various government institutions and NGOs are involved in social welfare programs, in particular education, health and sanitation. In addition to this, private sectors would align with the idea of publicprivate collaboration. Moreover, in recent days, the city has experienced the emergence of capitalintensive educational institutions and private clinics with a sense of apprehension for the wealthy population, which is also exacerbating social discrimination.

Therefore, a systemic solution will be a successful way to solve the diverse problems of urban slums with the cooperation and coordination of multiple players. In addition, the effective and equitable provision of enhanced municipal services, public infrastructure and facilities are essential elements that contribute to sustainable settlements.Hence, a better plan and good initiatives can eradicate these inequalities by managing minimum standard living facilities to slum areas of Dhaka city so that the dwellers can be more effective and accelerated the economic growth of Bangladesh.

\section{REFERENCES}

ADB. (2018, July 6). Poverty in Bangladesh. Asian Development Bank. https://www.adb. org/countries/ bangladesh/poverty

Aderamo, A. J. and Aina, O. A. (2011). Spatial inequalities in accessibility to social amenities in developing countries: A case from Nigeria. Australian Journal of Basic and Applied Sciences, 5(6), 316-322.

Afrin, S., Zerin, I., Sharmin, S., and Morshed, K. M. (2012). Transformation of Dhanmondi Residential AreaCauses, Effects and Proposal to Rejuvenate. Asian Journal of Applied Science and Engineering, 1(2), 31-47. http://journals.abc.us.org/index.php/ajase/article/view/2.3. 12.

Agarwal, S., and Taneja, S. (2005). All Slums are Not Equal: Child Health Conditions among the Urban Poor. INDIAN PEDIATRICS, 42(3), 233-244. https://nbnresolving.org/urn:nbn:de:0168-ssoar-46838-7.

Ahmed, B., Raj, M. R. H., and Maniruzzaman, K. (2009). Morphological Change of Dhaka City over a Period of 55 Years: A Case Study of Two Wards. Journal of Bangladesh Institute of Planners, 2, 30-38. https://doi.org/10.3329/jbip.v2i0.9554

Ahmed, I. (2014). Factors in building resilience in urban slums of Dhaka, Bangladesh. Procedia Economics and Finance, 18, 745-753. https://doi.org/10.1016/S2212-5671 (14)00998-8.

Ahmed, T., Mahfuz, M., Islam, M. M., Mondal, D., Hossain, M. I., Ahmed, A. S., Tofail, F., Gaffar, S. A., Haque, R., Guerrant, R. L., and Petri, W. A. (2014). The MAL-ED Cohort Study in Mirpur, Bangladesh. Clinical Infectious Diseases, 59(suppl_4), S280-S286. https://doi.org/10.1093/cid/ciu458

Alam, M., and Rabbani, M. D. G. (2007). Vulnerabilities and responses to climate change for Dhaka. Environment and Urbanization, 19(1), 81-97. https://doi.org/10.1177/0956247807076911

Aminu, A. (2017). Household Resource Management [Lecture Series]. https://www.academia.edu/ 6493437/Household_Resource_Management

Angeles, G., Lance, P., Barden-O'Fallon, J., Islam, N., Mahbub, A. Q. M., and Nazem, N. I. (2009). The 2005 census and mapping of slums in Bangladesh: Design, select results and application. International Journal of Health Geographics, 8(1), 32. 
Asim, M., Batool, S. A., and Chaudhry, M. N. (2012). Scavengers and their role in the recycling of waste in Southwestern Lahore. Resources, Conservation and Recycling, 58, 152-162. https://doi.org/ 10.1016/j. resconrec. 2011.10.013

Badhan, M. A., Roy, B., and Sifat, S. A. (2017). Water supply and sanitation situation of Kalyanpur slum area in Dhaka. International Journal of Natural and Social Sciences, 4(2), 6.

Bandara, A., Dehejia, R., and Lavie-Rouse, S. (2017). Access to Household Resources and Human Development: Evidence from Survey Data for Tanzania. Journal of Human Development and Capabilities, 18 (3), 399-423. https:// doi.org/10.1080/ 19452829.2016.1270920

Bartlet, S., Mitlin, D., and Satterthwaite, D. (2013). Urban Inequalities. Global Thematic Consultation, 113.

Barua, S., Mridha, A., and Khan, R. H. (2010). Housing Real Estate Sector in Bangladesh Present Status and Policies Implications. ASA University Review, 4(1), 240-253.

BBS (2010). The Household Income and Expenditure Report 2010 (p. 611). Bangladesh Bureau of Statistics, Statistics and Informatics Division, Ministry of Planning, Bangladesh, Government of the People's Republic of Bangladesh.

BBS, (2015). Census of Slum Areas and Floating Population 2014. Bangladesh Bureau of Statistics, Statistics and Informatics Division, Ministry of Planning, Government of the People's Republic of Bangladesh.

BBS, (2016). Bangladesh-Labour Force Survey 2013 (Labour Force Survey). Bangladesh Bureau of Statistics, Ministry of Planning, Government of the People's Republic of Bangladesh. https://www.ilo.org/surveydata/ index.php/catalog/1045

Begum, S., and Sen, B. (2005). Pulling rickshaws in the city of Dhaka: A way out of poverty? Environment and Urbanization, 17(2), 11-25. https://doi.org/10.1177/095624780501700202

Bhagat, R. B. (2010). Access to basic amenities in urban areas by size class of cities and towns in India. International Institute for Population Sciences, Mumbai-400088.

Braun, B., and Aßheuer, T. (2011). Floods in megacity environments: Vulnerability and coping strategies of slum dwellers in Dhaka/Bangladesh. Natural Hazards, 58(2), 771-787. https://doi.org/10.1007/s11069-0119752-5

Cohen, B. (2006). Urbanization in developing countries: Current trends, future projections, and key challenges for sustainability. Technology in Society, 28(1-2), 63-80. https://doi.org/10.1016/j.techsoc.2005.10.005

Dana, T. (2011). Unhygienic living conditions and health problems: A study in selected slums of Dhaka city. OIDA International Journal of Sustainable Development, 2(11), 27-34.

Farah, S., Karim, M., Akther, N., Begum, M., and Begum, N. (2015). Knowledge and Practice of Personal Hygiene and Sanitation: A Study in Selected Slums of Dhaka City. Delta Medical College Journal, 3(2), 68-73. https://doi.org/10.3329/dmcj.v3i2.24425

Grant, U. (2010). Spatial inequality and urban poverty traps (Working Paper No. 326; pp. 1-35). Chronic Poverty Research Centre.

Gruebner, O., Sachs, J., Nockert, A., Frings, M., Khan, M. M. H., Lakes, T., and Hostert, P. (2014). Mapping the Slums of Dhaka from 2006 to 2010. Dataset Papers in Science, 2014, 1-7. https://doi.org/10.1155/2014/172182

Hackenbroch, K., Hossain, M. S., and Rahman, M. A. (2008). Coping with forced evictions: Adaptation processes of evicted slum dwellers in Dhaka. Trialog, 98(3), 17-23.

Hanchett, S., Akhter, S., Khan, M. H., Mezulianik, S., and Blagbrough, V. (2003). Water, sanitation and hygiene in Bangladeshi slums: An evaluation of the WaterAid- Bangladesh urban programme. Environment and Urbanization, 15(2), 43-56. https://doi.org/10.1177/095624780301500219

Hanisch, M., Kimmich, C., Rommel, J., and Sagebiel, J. (2010). Coping with power scarcity in an emerging megacity: A consumers' perspective from Hyderabad. International Journal of Global Energy Issues, 33(3/4), 189. https://doi.org/10.1504/IJGEI.2010.036956

Hasnat, M., and Hoque, D. S. (2014). Reducing Congestion in Dhanmondi Residential Area: Introducing Cordon Pricing. International Journal of Advanced Engineering Research and Science, 1(5), 49-57.

Heath, R. (2014). Women's Access to Labor Market Opportunities, Control of Household Resources, and Domestic Violence: Evidence from Bangladesh. World 
Development, 57, 32-46.

https://doi.org/10.1016/j.worlddev.2013.10.028

Hewett, P. C., and Montgomery, M. (2001). Poverty and public services in developing-country cities (Vol. 154). Population Council New York.

Hossain, M. A., Moniruzzaman, M., and Islam, M. A. (2010). Urban environmental health in Bangladesh slum: A comparative study of two metropolitan cities. Journal of Science Foundation, 8(1-2), 67-76.

Hossain, M. S., Hossain, M., Hossain, S., and Rony, J. I. (2018). Analysis of Socio-Economic Conditions of Rickshaw Pullers in the Capital City of Bangladesh. European Journal of Business and Management, 10(23), 9. www.iiste.org

Hossain, S. (2004). Urban poverty and household adaptations in Dhaka City, Bangladesh. Revisioning Institutions: Change in the 21 St Century, 13.

Hossain, S. (2005). Poverty, household strategies and coping with urban life: Examining 'livelihood framework' in Dhaka city, Bangladesh. Bangladesh EJournal of Sociology, 2(1), 1-8.

Hossain, S. (2008). Rapid Urban Growth and Poverty in Dhaka City. Bangladesh E-Journal of Sociology, 5(1), 24.

Hossain, S. (2006). Social characteristics of a megacity: A case of Dhaka City, Bangladesh. Conference Proceedings, 10.

INSEE. (2016). Household resources [Organization]. https://www.insee.fr/en/metadonnees/definition/c1215

Islam, N., Angeles, G., Mahbub, A., Lance, P., and Nazem, N. I. (2006). Slums of urban Bangladesh: Mapping and census 2005. Centre for Urban Studies, National Institute of Population Research and Training, and MEASURE Evaluation.

Jahan, S., and Oda, T. (2000). Distribution of public facilities in Dhaka, Bangladesh: A spatial analysis. Bulletin of the Faculty of Human Development, 7(2), 865-874.

Kamruzzaman, M., and Hakim, M. A. (2016). Socioeconomic Status of Slum Dwellers: An Empirical Study on the Capital City of Bangladesh. American Journal of Business and Society, 1(2), 13-18. http://www.aiscience.org/journal/ajbs

Kanbur, R., andand Venables, A. J. (2003). Spatial Inequality and Development. Charles H. Dyson School of Applied Economics and Management, Cornell University, 18.
Kim, S. (2008). Spatial inequality and economic development: Theories, facts, and policies. Urbanization and Growth, 133-166. http://documents.worldbank.org/curated/en/803661468 330972127/pdf/577160NWP0Box353766B01PUBLIC 10gcwp016web.pdf

Kimani-Murage, E. W., and Ngindu, A. M. (2007). Quality of Water the Slum Dwellers Use: The Case of a Kenyan Slum. Journal of Urban Health, 84(6), 829838. https://doi.org/10.1007/s11524-007-9199-x

Kumar, N., and Aggarwal, S. C. (2003). Patterns of consumption and poverty in Delhi slums. Economic and Political Weekly, 38(50), 5294-5300. http://www.jstor.org/stable/4414404

Labib, S. M., Bhuiya, M. M. R., and Rahaman, M. Z. (2013). Location and size preference for apartments in Dhaka and prospect of real estate market. Bangladesh Research Publications Journal, 9(2), 87-96.

Latif, M. B., Irin, A., and Ferdaus, J. (2016). Socioeconomic and health status of slum dwellers of the Kalyanpur slum in Dhaka city. Bangladesh Journal of Scientific Research, 29(1), 73-83. https://doi.org/10.3329/bjsr.v29i1.29760

Mahbub-Un-Nabi, A. S. M., and Hashem, M. (2007). Trends of Development in Dhanmondi. Urbanization in Bangladesh-Patterns, Issues and Approaches to Planning, 36-42.

McGranahan, D. A. (1999). Natural amenities drive rural population change (Agriculture Economic Report No. 781; p. 27). Food and Rural Economics Division, Economic Research Service, U.S department of Agriculture.

Mensah, J. T., and Adu, G. (2015). An empirical analysis of household energy choice in Ghana. Renewable and Sustainable Energy Reviews, 51, 14021411. https://doi.org/10.1016/j.rser.2015.07.050

Mohit, M. A. (2012). Bastee settlements of Dhaka City, Bangladesh: A review of policy approaches and challenges ahead. Procedia-Social and Behavioral Sciences, 36, 611-622.

Mondal, S. H. (2017). Urban Informal Economy in Bangladesh: A Case Study on Mobile Vegetable Vendor in Dhaka City. The Qualitative Report, 22(11), 2893-2903.

https://nsuworks.nova.edu/tqr/vol22/iss11/4

Murali, V., and Oyebode, F. (2004). Poverty, social inequality and mental health. Advances in Psychiatric Treatment, 10(3), 216-224.

https://ecommons.cornell.edu/handle/1813/57957 
Niger, M. (2012). Transformation and changing trend of urban living spaces: A case of Dhaka city. Asian Journal of Applied Science and Engineering, 1(2), 2030.

Pachauri, S., van Ruijven, B. J., Nagai, Y., Riahi, K., van Vuuren, D. P., Brew-Hammond, A., and Nakicenovic, N. (2013). Pathways to achieve universal household access to modern energy by 2030 . Environmental Research Letters, 8(2), 024015. https://doi.org/10.1088/1748-9326/8/2/024015

Parry, J. A., Ganaie, S. A., Nengroo, Z. A., and Bhat, M. S. (2012). Spatial Analysis on the provision of Urban Amenities and their Deficiencies-A Case Study of Srinagar City, Jammu and Kashmir, India. Research on Humanities and Social Sciences, 2(6), 192-218.

Sagebiel, J., and Rommel, K. (2014). Preferences for electricity supply attributes in emerging megacitiesPolicy implications from a discrete choice experiment of private households in Hyderabad, India. Energy for Sustainable Development, 21, 89-99. https://doi.org/10.1016/j.esd.2014.06.002

Sekhampu, T. J., and Niyimbanira, F. (2013). Analysis of the Factors Influencing Household Expenditure in A South African Township. International Business and Economics Research Journal (IBER), 12(3), 279.https://doi.org/10.19030/iber.v12i3.7671

Sinthia, S. A. (2013). Sustainable Urban Development of Slum Prone Area of Dhaka City. International Journal of Economics and Management Engineering, $7(3), 8$.
Stubbs, J., and Clarke, G. (1996). Megacity management in the Asian and Pacific region: Policy issues and innovative approaches (Vol. 2). Asian Development Bank.

The Daily Star. (2019, January 13). Living cost in Dhaka rose by 6 per cent in 2018. https://www.thedailystar.net/business/living-cost-indhaka-rose-6-per-cent-in-2018-1686520

Townsend, P. (1979). Poverty in the United Kingdom: A survey of household resources and standards of living (1st ed.). University of California Press.

United Nations. (2018). World Urbanization Prospects: The 2018 Revision. United Nations Department of Economic and Social Affairs, Population Division, Online edition. https://www.un.org/development/desa/publications/201 8-revision-of-world-urbanization-prospects.html

Warwick, K. (2018). 6 Community Amenities You Need in Your Neighbourhood. http:// blog. qualicocommunities edmonton. com/ blog/communityamenities-need-neighbourhood

Yalcintas, M. and Kaya, A. (2017). Roles of income, price and household size on residential electricity consumption: Comparison of Hawaii with similar climate zone states. Energy Reports, 3, 109-118. https://doi.org/10.1016/j.egyr.2017.07.002

Zayeed, A. A. (2016). Informal Sector and its impact on Dhaka. The Opinion Pages. https://opinion.bdnews24.com/2016/04/11/informalsector-and-its-impact-on-dhaka/ 